Utah State University

DigitalCommons@USU

1995

\title{
Carbon allocation and partitioning in aspen clones varying in sensitivity to tropospheric ozone
}

\author{
M.D. Coleman \\ R.E. Dickson \\ J.G. Isebrands \\ D.F. Karnosky
}

Follow this and additional works at: https://digitalcommons.usu.edu/aspen_bib

Part of the Forest Sciences Commons

\section{Recommended Citation}

M.D. Coleman et al. 1995. Carbon allocation and partitioning in aspen clones varying in sensitivity to tropospheric. Heron Publishing. Tree Physiology. 15 (9): 593-604

This Article is brought to you for free and open access by the Aspen Research at DigitalCommons@USU. It has been accepted for inclusion in Aspen Bibliography by an authorized administrator of DigitalCommons@USU. For more information, please contact

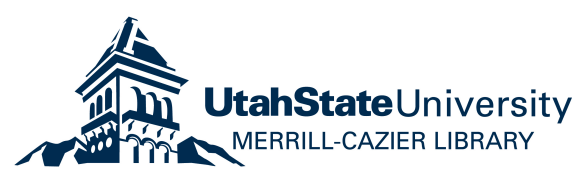




\title{
Carbon allocation and partitioning in aspen clones varying in sensitivity to tropospheric ozone
}

\author{
M. D. COLEMAN, ${ }^{1}$ R. E. DICKSON, ${ }^{1,3}$ J. G. ISEBRANDS ${ }^{1}$ and D. F. KARNOSKY ${ }^{2}$ \\ ${ }^{1}$ USDA Forest Service, North Central Forest Experiment Station, Forestry Sciences Laboratory, P.O. Bo898, Rhinelander, WI 54501, USA \\ 2 School of Forestry and Wood Products, Michigan Technological University, Houghton, MI 49931, USA \\ ${ }^{3}$ Author to whom correspondence should be addressed
}

Received August 13, 1993

\begin{abstract}
Summary Clones of aspen (Populus tremuloides Michx.) were identified that differ in biomass production in response to $\mathrm{O}_{3}$ exposure. ${ }^{14} \mathrm{Carbon}$ tracer studies were used to determine if the differences in biomass response were linked to shifts in carbon allocation and carbon partitioning patterns. Rooted cuttings from three aspen Clones $\left(216, \mathrm{O}_{3}\right.$ tolerant; 271 , intermediate; and 259, $\mathrm{O}_{3}$ sensitive) were exposed to either charcoal-filtered air (CF) or an episodic, two-times-ambient $\mathrm{O}_{3}$ profile $(2 \times)$ in open-top chambers. Either recently mature or mature leaves were exposed to a $30-\min { }^{14} \mathrm{C}$ pulse and returned to the treatment chambers for a 48 -h chase period before harvest. Allocation of ${ }^{14} \mathrm{C}$ to different plant parts, partitioning of ${ }^{14} \mathrm{C}$ into various chemical fractions, and the concentration of various chemical fractions in plant tissue were determined. The percent of ${ }^{14} \mathrm{C}$ retained in recently mature source leaves was not affected by $\mathrm{O}_{3}$ treatment, but that retained in mature source leaves was greater in $\mathrm{O}_{3}$-treated plants than in $\mathrm{CF}$-treated plants. Carbon allocation from source leaves was affected by leaf position, season, clone and $\mathrm{O}_{3}$ exposure. Recently mature

by photosynthesis in the source leaves than proportional changes in allocation to the sinks. Ozone decreased the total amount of carbon translocated to all sink tissue in the $\mathrm{O}_{3}$-sensitive Clone 259 because of decreases in photosynthesis in both recently mature and mature source leaves. In contrast, $\mathrm{O}_{3}$ had no effect on carbon transport from recently mature leaves to lower shoots of either Clone 216 or 271 , had no significant effect on transport to roots of Clone 216, and increased transport to roots of Clone 271. The $\mathrm{O}_{3}$-induced increase in transport to roots of Clone 271 was the result of a compensatory increase in upper leaf photosynthesis and a relatively greater shift in the percent of carbon allocated to roots. In contrast to those of Clone 271, recently mature leaves of Clone 216 maintained similar photosynthetic rates and allocation patterns in both the $\mathrm{CF}$ and $\mathrm{O}_{3}$ treatments. We conclude that Clone 271 was more tolerant to $\mathrm{O}_{3}$ exposure than Clone 216 or 259 . Tolerance to chronic $\mathrm{O}_{3}$ exposure was directly related to maintenance of high photosynthetic rates in recently mature leaves and retention of lower leaves.
\end{abstract} source leaves of $\mathrm{CF}$-treated plants translocated about equal percentages of ${ }^{14} \mathrm{C}$ acropetally to growing shoots and basipetally to stem and roots early in the season. When shoot growth ceased (August 16), most ${ }^{14} \mathrm{C}$ from all source leaves was translocated basipetally to stem and roots. At no time did mature source leaves allocate more than $6 \%$ of ${ }^{14} \mathrm{C}$ translocated within the plant to the shoot above. Ozone effects were most apparent late in the season. Ozone decreased the percent ${ }^{14} \mathrm{C}$ translocated from mature source leaves to roots and increased the percent ${ }^{14} \mathrm{C}$ translocated to the lower stem. In contrast, allocation from recently mature leaves to roots increased. Partitioning of ${ }^{14} \mathrm{C}$ among chemical fractions was affected by $\mathrm{O}_{3}$ more in source leaves than in sink tissue. In source leaves, more ${ }^{14} \mathrm{C}$ was incorporated into the sugar, organic acid and lipids + pigments fractions, and less ${ }^{14} \mathrm{C}$ was incorporated into starch and protein fractions in $\mathrm{O}_{3}$-treated plants than in CFtreated plants. In addition, there were $\mathrm{O}_{3}$ treatment interactions between leaf position and clones for ${ }^{14} \mathrm{C}$ incorporation into different chemical fractions.

When photosynthetic data were used to convert percent ${ }^{14} \mathrm{C}$ transported to the total amount of carbon transported on a mass basis, it was found that carbon transport was controlled more
Keywords: air pollution, carbohydrates, photosynthesis, Рориlus tremuloides.

\section{Introduction}

Carbon allocation in indeterminate woody plant species such as trembling aspen (Populus tremuloides Michx.) follows a predictable seasonal pattern. During active shoot growth, carbon allocation, especially from recently mature leaves, is primarily upward toward the growing shoot. As shoot growth slows, more carbon is allocated to stem and root growth and storage. Mature leaves lower on the stem export most fixed carbon to the lower stem and roots throughout the season (Dickson 1986, 1991).

Tropospheric $\mathrm{O}_{3}$ affects carbon allocation patterns of woody plants in several ways. Compared to unstressed plants, greater amounts of carbon are retained in the foliage or shoot tissue (Brouwer 1983). In herbaceous crop plants, $\mathrm{O}_{3}$ decreases root biomass relative to shoot biomass (Cooley and Manning 1987), and this response is related to changes in whole-plant carbon allocation patterns (Blum et al. 1982, McCool and 
Menge 1983, McLaughlin and McConathy 1983). Studies of $\mathrm{O}_{3}$ effects on carbon allocation in trees have primarily involved conifers (Adams et al. 1990), which are considerably less sensitive to $\mathrm{O}_{3}$ than herbaceous crops (Reich 1987, Gorissen and van Veen 1988, Spence et al. 1990, Adams and O'Neill 1991, Gorissen et al. 1991 a, 1991b). In contrast to crop plants and conifers, little information is available concerning $\mathrm{O}_{3}$ effects on carbon allocation in hardwood tree species.

Alterations in carbon partitioning in source leaves that favor either starch or sugar accumulation is another characteristic stress response in plants (Dickson and Isebrands 1991). Stress may also induce a shift from starch reserves to sugars and other compounds associated with tissue repair (Tingey 1974, Meier et al. 1990, Bücker and Ballach 1992).

There have been few studies of genetic variation in plant response to $\mathrm{O}_{3}$ (Butler and Tibbitts 1979, Heck et al. 1988, Gillespie and Winner 1989), and in particular, of carbon allocation responses (McLaughlin and McConathy 1983, Adams and O'Neill 1991). We have, therefore, examined carbon allocation and partitioning responses of aspen clones differing in biomass response to $\mathrm{O}_{3}$. Following the terminology outlined by Dickson and Isebrands (1993), where carbon allocation refers to translocation of carbon from source leaves to sink tissue, and carbon partitioning refers to the movement of carbon among the various chemical fractions within a particular tissue, we postulated that clonal differences in response to $\mathrm{O}_{3}$ reflect differences in carbon allocation between shoot and root, and in carbon partitioning among chemical fractions that favor carbon retention in source leaves.

\section{Materials and methods}

Aspen clones ranging in sensitivity to $\mathrm{O}_{3}\left(216, \mathrm{O}_{3}\right.$ tolerant; 271 , intermediate; and $259, \mathrm{O}_{3}$ sensitive) were selected based on susceptibility to foliar injury and decreases in biomass after $\mathrm{O}_{3}$ exposure (Karnosky et al. 1992). However, these $\mathrm{O}_{3}$-sensitivity rankings change depending on the response parameter measured. Experimental plants were vegetatively propagated as softwood cuttings as described by Coleman et al. (1995).

\section{Ozone exposures}

Episodic treatments were derived from hourly ambient profiles constructed from $\mathrm{O}_{3}$ data collected in Michigan's Lower Peninsula in cooperation with the U.S. Environmental Protection Agency (Coleman et al. 1995). The simulated ambient profile was doubled to give a twice ambient $(2 x)$ exposure. Ozone for the twice ambient treatments, hereafter referred to as $\mathrm{O}_{3}$ treatment or $2 \times$ exposure, was generated with an OREC V $10-0 \mathrm{O}_{3}$ generator with oxygen as the source and dispensed into charcoal-filtered air (CF) in open-top chambers. There were three chambers for each $\mathrm{CF}$ and $\mathrm{O}_{3}$ treatment. Mean hourly $\mathrm{O}_{3}$ concentrations for each chamber were recorded and summed over the growing season to quantify cumulative $\mathrm{O}_{3}$ dose (Table 1).

\section{Labeling with ${ }^{14} \mathrm{CO}_{2}$}

Plants were labeled with ${ }^{14} \mathrm{CO}_{2}(25 \mu \mathrm{Ci})$ three times during the 1990 growing season: on July 2 to 4 , July 23 to 25 , and August 14 to 16 . All plants from one replicate $\mathrm{O}_{3}$ chamber and one replicate $\mathrm{CF}$ chamber were labeled in one day. Because there were three replicate chambers per treatment, it took 3 days to label all plants. Two plants to provide two leaf positions for each of three clones were labeled in each chamber. Recently mature source leaves were first labeled on one plant, then mature source leaves were labeled on the second (Figure 1). Plants were labeled under natural light conditions within $2 \mathrm{~h}$ of solar noon as described by Isebrands and Dickson (1991). Three leaves from the specified age class were enclosed in a mylar bag. The bag was sealed to the stem above the source leaves and closed with adhesive tape and cinched around the stem below the source leaves with flexible wire. Labeled carbon dioxide $\left({ }^{14} \mathrm{CO}_{2}\right)$ was generated inside the bag by injecting lactic acid into a cup containing a ${ }^{14} \mathrm{C}$ sodium bicarbonate precipitate. During the 30 -min pulse treatment, the bag was periodically flexed to ensure circulation of the ${ }^{14} \mathrm{CO}_{2}$. After the

Table 1. Ozone exposure data for the three experimental harvest times, including the 24-h cumulative hourly $\mathrm{O}_{3}$ dose for both $\mathrm{CF}$ and $2 \times \mathrm{O}_{3}$ treatments, and the number of hours that average hourly $\mathrm{O}_{3}$ concentration exceeded either 100 or $145 \mathrm{ppb}$ in the $2 \times$ treatment. The maximum daily exposures recorded were $34 \mathrm{ppb}$ in the CF treatment and $149 \mathrm{ppb}$ in the $2 \times$ treatment.

\begin{tabular}{llllll}
\hline Harvest date & \multicolumn{2}{l}{ Ozone dose $(\mathrm{ppm}-\mathrm{h})$} & & \multicolumn{2}{l}{ Number of hours exceeding } \\
\cline { 2 - 3 } \cline { 5 - 6 } \cline { 5 - 6 } & CF & $2 \times$ & & $100 \mathrm{ppb}$ & $145 \mathrm{ppb}$ \\
\hline July 4 & 2 & 6 & & 2 & 0 \\
July 25 & 3 & 21 & & 47 & 1 \\
August 16 & 7 & 56 & & 79 & 2 \\
\hline
\end{tabular}

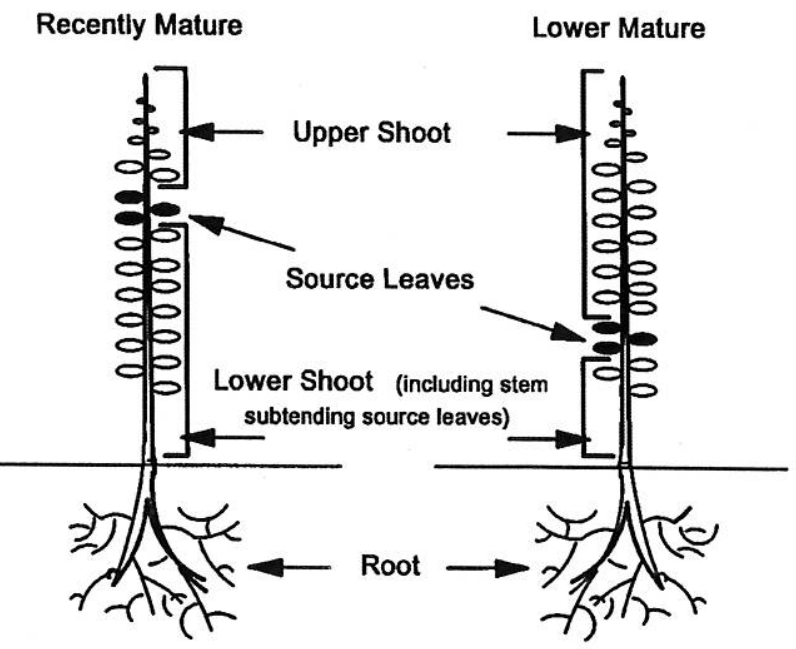

Figure 1. Diagram of the two source leaf positions (recently mature and mature) that were labeled with ${ }^{14} \mathrm{CO}_{2}$. Three leaves were labeled at each leaf position. Labeling at different leaf positions required that plant tissue types be grouped differently at harvest. The differences in tissue grouping between the two source leaf positions are shown. 
30-min pulse, any remaining ${ }^{14} \mathrm{CO}_{2}$ was withdrawn through tubing attached to the bag with a plastic quick-connect valve, and was scrubbed into a sodium hydroxide trap.

To determine the initial amount of ${ }^{14} \mathrm{C}$ fixed, one disc $\left(0.6 \mathrm{~cm}^{2}\right)$ was taken from each of the three source leaves immediately after the mylar bag was removed. After labeling, the plants were returned to their respective open-top treatment chambers for $48 \mathrm{~h}$ and then harvested. At harvest, each plant was divided into eight components: source leaves, leaves above the source, leaves below the source, stem segments of source leaves, stem above the source, stem below the source, coarse roots, and fine roots (less than $1 \mathrm{~mm}$ diameter). Each tissue was dried at $60{ }^{\circ} \mathrm{C}$, weighed and ground with a Wiley mill to pass a 40-mesh screen. Leaf discs were solubilized with BTS-450 and then mixed with Ready-Organic scintillation cocktail (Beckman Scintillation Supplies, Fullerton, CA, USA; mention of trade names or companies does not indicate endorsement by the USDA Forest Service), and ${ }^{14} \mathrm{C}$ was determined by liquid scintillation spectrometry. Subsamples of ground tissue were suspended in a phase-combining scintillation cocktail (PCS, Amersham Corp., Arlington Heights, IL, USA) to determine ${ }^{14} \mathrm{C}$ (Isebrands and Dickson 1991).

The quantities of ${ }^{14} \mathrm{C}$ fixed, respired, translocated to sinks, or retained in source leaves were determined from the total radioactivity in each tissue component. The amount of ${ }^{14} \mathrm{C}$ fixed in source leaves was estimated as the product of leaf disc ${ }^{14} \mathrm{C}$ (expressed on an area basis) and the total area of source leaves. The ${ }^{14} \mathrm{C}$ fixed was then divided into either the percentage recovered in the various plant tissues or the amount lost, mainly to respiration, during the chase period (calculated as total ${ }^{14} \mathrm{C}$ fixed $-{ }^{14} \mathrm{C}$ recovered). The amount of ${ }^{14} \mathrm{C}$ recovered following the 48-h chase period was the product of tissue dry weight and specific activity. Total ${ }^{14} \mathrm{C}$ recovered was the sum of ${ }^{14} \mathrm{C}$ recovered in all tissue components. The amount lost was expressed as a percent of that fixed to estimate the percent respired. The percent ${ }^{14} \mathrm{C}$ retained in source leaves was expressed as a percent of the total recovered. The percent ${ }^{14} \mathrm{C}$ translocated during the chase period was the percentage of the total recovered that was found in all sink tissues. In addition, ${ }^{14} \mathrm{C}$ translocated was further subdivided into the percentage found in each sink tissue.

\section{Biochemical analysis}

Carbon partitioning was determined to evaluate fluxes of ${ }^{14} \mathrm{C}$ into various chemical fractions (Dickson 1979, Isebrands and Dickson 1991). This method involves the sequential extraction of tissue samples into several biochemical fractions that can be either counted to determine ${ }^{14} \mathrm{C}$, or quantitatively analyzed to determine the size of each pool (e.g., total soluble sugars, starch, amino acids, etc.). Only tissue samples (source leaves, lower stems and course roots) collected in mid-August were used for ${ }^{14} \mathrm{C}$ chemical partitioning and chemical analysis. Because the percentage of ${ }^{14} \mathrm{C}$ found in the different chemical fractions after labeling either of the two source leaf positions did not differ in lower stem or roots, the ${ }^{14} \mathrm{C}$ data from both of these labeling positions were pooled for statistical analyses of the stem and root tissues.

\section{Estimated carbon fixation and translocation}

Photosynthetic carbon fixation was measured on a companion set of plants that were treated like those used for the ${ }^{14} \mathrm{C}$ experiments (Coleman et al. 1995). Briefly, photosynthetic fixation rate of each leaf age class was determined and that rate was multiplied by the total leaf area of that leaf age class. To estimate the amount of carbon fixed and translocated to each sink tissue, the quantity of carbon fixed by each leaf age class was multiplied by the percent translocated to determine total carbon translocated. Total carbon translocated was then subdivided into the percent translocated to each sink tissue.

\section{Statistical analysis}

The carbon allocation data were subjected to analysis of variance in a four-way factorial design. The four factors in the design were $\mathrm{O}_{3}$ treatment, harvest, clone and leaf position. Statistical evaluation of biochemical and carbon translocation data included only one harvest and was, therefore, a three-factor design. Because the $\mathrm{O}_{3}$ treatment was within open-top chambers, a split-plot analysis was employed. The main-plot error (four degrees of freedom) was used to test treatment and harvest effects, and the split-plot error (eight degrees of freedom) was used to test clone and leaf position effects. All statistical analyses were performed with the SYSTAT software package (Wilkinson 1990).

\section{Results}

\section{Ozone exposures}

By August 16, the total $\mathrm{O}_{3}$ dose accumulated over the season was $56 \mathrm{ppm}-\mathrm{h}$ (Table 1). Individual daily episodic exposures occasionally exceeded $100 \mathrm{ppb}$ but rarely exceeded $140 \mathrm{ppb}$. These exposures are within the range occurring over much of central and eastern United States (Lefohn and Pinkerton 1988, Anonymous 1993). However, even these low ozone exposures caused foliar injury symptoms on each of the clones. As the season progressed, the effects of the $\mathrm{O}_{3}$ treatment on the oldest leaves became more pronounced until the leaves abscised (Karnosky, unpublished data). Because of foliar injury, photosynthetic rate and total carbon fixation decreased (Coleman et al. 1995). Declines in productivity were evident from biomass measurements of plants at the end of the season, and were most pronounced in the $\mathrm{O}_{3}$-sensitive Clone 259 (Karnosky, unpublished data).

\section{Fixation of ${ }^{14} C$}

Because of variability associated with the field mylar bag technique, no patterns of total ${ }^{14} \mathrm{C}$ fixation related to leaf position, $\mathrm{O}_{3}$ treatment or clone were found (Table 2). However, during the season, the amount of ${ }^{14} \mathrm{C}$ fixed decreased from $48 \%$ of that applied during the July 4 exposure period to $32 \%$ of that applied during the August 16 exposure period. The amount of ${ }^{14} \mathrm{C}$ fixed during the 30-min pulse ranged from 10 to $60 \%$ of that applied among individual plants (coefficient of variation 10 to $80 \%$ ). Such high variability is common in both indoor and field experiments and requires that the results be examined 
Table 2. Probability values for the percentage of total ${ }^{14} \mathrm{C}$ initially fixed in source leaves, recovered in the whole plant, retained in source leaves, and found in various plant components. Each parameter analysis of variance was based on a spit-plot design that included $\mathrm{O}_{3}$ treatment and harvest as whole-plot factors, and clone and leaf position as split-plot factors.

\begin{tabular}{|c|c|c|c|c|c|c|}
\hline \multirow[t]{2}{*}{ Variation } & \multirow{2}{*}{$\%{ }^{14} \mathrm{C}$ Fixed } & \multirow[t]{2}{*}{$\%{ }^{14} \mathrm{C}$ Recovered } & \multirow[t]{2}{*}{$\%{ }^{14} \mathrm{C}$ Retained } & \multicolumn{3}{|c|}{$\%{ }^{14} \mathrm{C}$ Allocated within the plant } \\
\hline & & & & Upper shoot & Lower shoot & Roots \\
\hline Ozone (O) & 0.811 & 0.912 & 0.573 & 0.127 & 0.016 & 0.599 \\
\hline Harvest $(\mathrm{H})$ & $0.000^{1}$ & 0.351 & 0.418 & $<0.001$ & $<0.001$ & $<0.001$ \\
\hline Clone (C) & 0.159 & 0.003 & 0.024 & 0.002 & 0.022 & 0.431 \\
\hline Position (P) & 0.108 & 0.003 & 0.009 & $<0.001$ & 0.004 & $<0.001$ \\
\hline $\mathrm{O} \times \mathrm{C}$ & 0.340 & 0.927 & 0.131 & 0.036 & 0.191 & 0.918 \\
\hline $\mathrm{O} \times \mathrm{P}$ & 0.514 & 0.149 & 0.004 & 0.018 & 0.578 & 0.017 \\
\hline $\mathrm{O} \times \mathrm{H}$ & 0.066 & 0.525 & 0.592 & 0.719 & 0.395 & 0.924 \\
\hline $\mathrm{C} \times \mathrm{P}$ & 0.033 & 0.424 & 0.162 & 0.001 & 0.620 & 0.001 \\
\hline $\mathrm{C} \times \mathrm{H}$ & 0.058 & 0.012 & 0.463 & 0.177 & 0.651 & 0.558 \\
\hline $\mathrm{P} \times \mathrm{H}$ & 0.390 & 0.219 & 0.128 & $<0.001$ & 0.072 & 0.001 \\
\hline $\mathrm{O} \times \mathrm{C} \times \mathrm{P}$ & 0.070 & 0.479 & 0.305 & 0.122 & 0.694 & 0.451 \\
\hline $\mathrm{O} \times \mathrm{C} \times \mathrm{H}$ & 0.026 & 0.198 & 0.558 & 0.863 & 0.550 & 0.556 \\
\hline $\mathrm{O} \times \mathrm{P} \times \mathrm{H}$ & 0.448 & 0.491 & 0.506 & 0.355 & 0.402 & 0.206 \\
\hline $\mathrm{C} \times \mathrm{P} \times \mathrm{H}$ & 0.014 & 0.088 & 0.222 & 0.184 & 0.561 & 0.798 \\
\hline
\end{tabular}

1 Probability values less than 0.10 are considered significant.

on a proportional basis (Isebrands and Dickson 1991). Thus, the patterns of ${ }^{14} \mathrm{C}$ allocation within the plant based on the percentage of ${ }^{14} \mathrm{C}$ found in different plant parts are the same regardless of the total amount initially fixed.

The $\mathrm{O}_{3}$ treatment had no consistent effect on the percent ${ }^{14} \mathrm{C}$ recovered after the 48 -h chase period (Table $2, P=0.912$ ) except when mature leaves of Clone 216 were treated in August (Figure 2). Clonal and leaf positional effects were significant. In general, more ${ }^{14} \mathrm{C}$ was recovered in Clone 216 than in the other clones, and less ${ }^{14} \mathrm{C}$ was recovered from plants

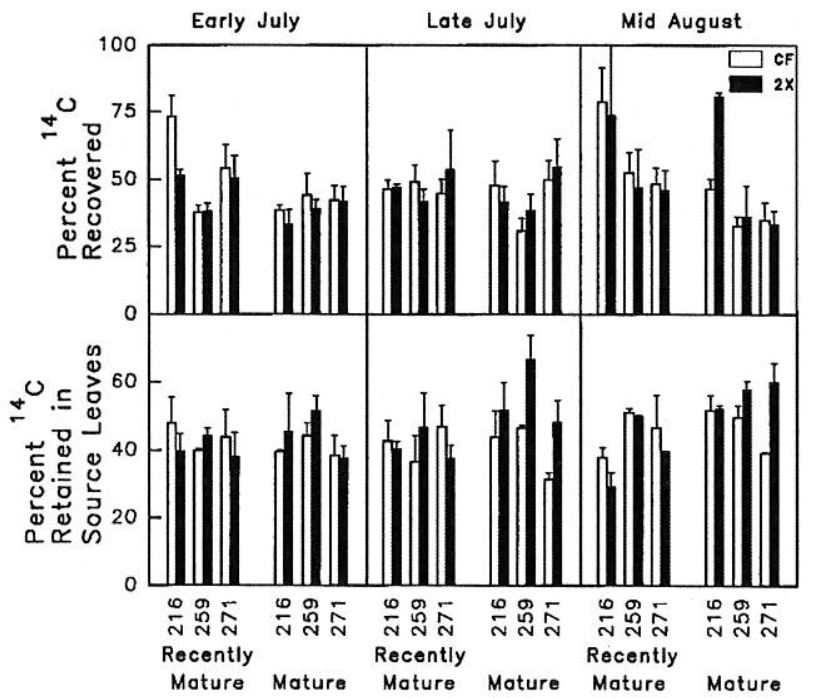

Figure 2. Effects of $\mathrm{O}_{3}$ exposure on the percentage of ${ }^{14} \mathrm{C}$ recovered in plants and retained in source leaves. Labeled $\mathrm{CO}_{2}$ was applied to recently mature and mature leaves, and the plants were harvested after a 48-h chase period. Three aspen clones $(216,259$ and 271$)$ were treated three times during the season. Ozone treatments were charcoalfiltered air (CF) and twice ambient $\mathrm{O}_{3}(2 \times)$. Each error bar represents the standard error of three replicate samples. labeled at the mature leaf position than from plants labeled at the recently mature leaf position (Figure 2).

\section{Carbon allocation}

Retention of ${ }^{14} \mathrm{C}$ in source leaves The $\mathrm{O}_{3}$ treatment had no consistent effect on the ${ }^{14} \mathrm{C}$ retained in source leaves (Table 2); however, percent ${ }^{14} \mathrm{C}$ retained in source leaves differed with leaf position and among clones (Figure 2). For the final two experimental times, recently mature source leaves retained significantly less ${ }^{14} \mathrm{C}$ than mature source leaves (Figure 2, Table 2). When the two leaf positions were analyzed individually, there was no $\mathrm{O}_{3}$ treatment effect on recently mature source leaves $(P>0.31)$; however, mature source leaves of $\mathrm{O}_{3}$-treated plants retained a significantly greater percent ${ }^{14} \mathrm{C}$ than leaves of CF-treated plants in both late July $(\mathrm{P}=0.009)$ and mid-August $(P=0.007)$ (Figure 2$)$. The significant $\mathrm{O}_{3} \times$ leaf position interaction, which was greater in Clones 259 and 271 than in Clone 216, indicates that the mature and recently mature source leaves reacted differently to $\mathrm{O}_{3}$ treatment (Table 2). For example, recently mature source leaves of Clone 271 retained more ${ }^{14} \mathrm{C}$ in $\mathrm{CF}$-treated plants, whereas mature source leaves retained more ${ }^{14} \mathrm{C}$ in $\mathrm{O}_{3}$-treated plants (Figure 2).

Translocation of ${ }^{14} \mathrm{C}$ to sink tissues The average percentage distributions of ${ }^{14} \mathrm{C}$ in leaf, stem and root fractions were as follows. Leaves above the source contained $47 \%$ of the ${ }^{14} \mathrm{C}$ in the shoot above the source; leaves below the source contained $3 \%$ of the ${ }^{14} \mathrm{C}$ in the shoot below the source; and fine roots contained $27 \%$ of the total ${ }^{14} \mathrm{C}$ in roots. Because there were no important seasonal, $\mathrm{O}_{3}$ treatment or clonal effects on carbon allocation patterns between leaves and stems or between fine and coarse roots (excluding source leaves), leaves and stems were combined to form the upper shoot and lower shoot sinks, and fine and coarse root were combined to form the root sink (Figure 3). 
The proportion of ${ }^{14} \mathrm{C}$ allocated from recently mature source leaves to various sink tissues was more affected by growth stage of the plants than by any other factor (Figure 3, Table 2). During active shoot growth in early July, 40 to $70 \%$ of the carbon translocated from recently mature source leaves was allocated acropetally to the growing shoot. By late July, this proportion had dropped to nearly $30 \%$ in Clone 216 , but remained about $60 \%$ for Clone 271. In mid-August, when terminal buds had developed on all plants except some plants of Clone 271 and leaf expansion was complete in Clones 216 and 259 , the proportion of ${ }^{14} \mathrm{C}$ allocated acropetally was negligible except for the plants of Clone 271 that continued to produce leaves. The greater acropetal than basipetal allocation from recently mature source leaves early in the season is indicated by significant position and position $\times$ harvest interaction for percent ${ }^{14} \mathrm{C}$ allocated to the upper shoot (Table 2). Basipetal allocation from recently mature leaves to lower shoot and roots increased during the season as allocation to the upper shoot decreased (Figure 3). In early July, less than $15 \%$ of ${ }^{14} \mathrm{C}$ allocated from recently mature leaves was found in roots. By mid-August, ${ }^{14} \mathrm{C}$ allocated from recently mature leaves to roots exceeded $30 \%$ in all but the CF-treated plants of Clone 271 (Figure 3).

There was a significant difference in ${ }^{14} \mathrm{C}$ allocation to sinks associated with leaf position (Table 2, Figure 3) that was also dependent on harvest time; and there was a significant position by harvest interaction (Table 2) resulting from changes in

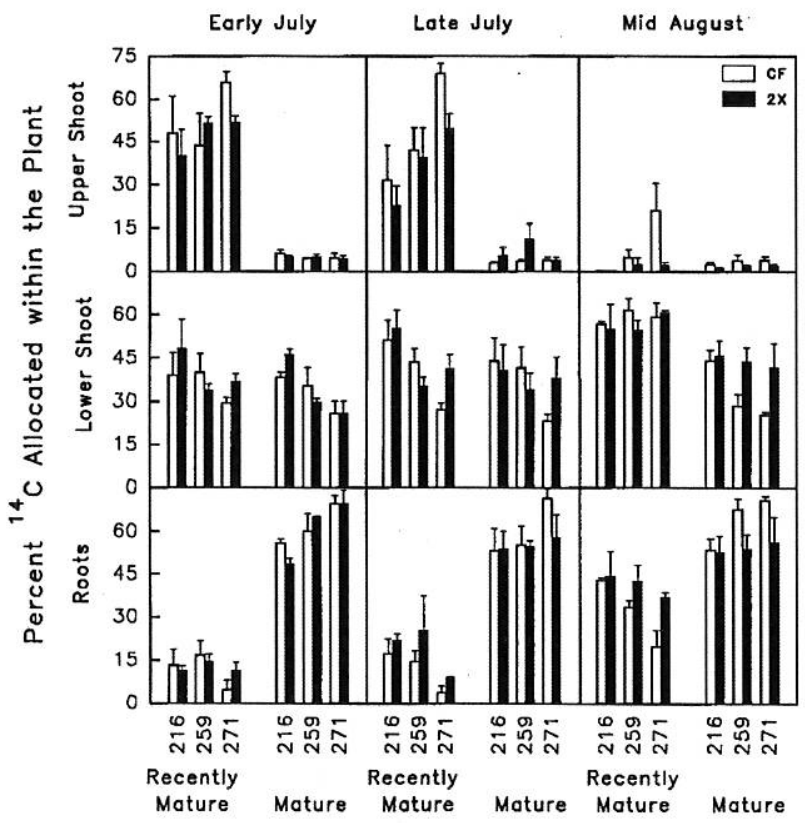

Figure 3. Effects of $\mathrm{O}_{3}$ exposure on ${ }^{14} \mathrm{C}$ allocation within the plants. Sink tissue types (upper shoot, lower shoot and root) are diagramed in Figure 1. Labeled $\mathrm{CO}_{2}$ was applied to recently mature and mature leaves, and the plants were harvested after a 48 -h chase period. Three aspen clones $(216,259$ and 271$)$ were treated three times during the season. Ozone treatments were charcoal-filtered air (CF) and twice ambient $\mathrm{O}_{3}(2 \times)$. Each error bar represents the standard error of three replicate samples. patterns of allocation from recently mature leaves. The patterns of carbon allocation from mature leaves to upper shoot, lower shoot and roots were similar during the entire season (Figure 3). In general, the proportion of ${ }^{14} \mathrm{C}$ recovered in shoots above mature source leaves was less than $6 \%$ of the total found in sink tissue during the entire season (Figure 3). Concomitantly, the percent ${ }^{14} \mathrm{C}$ allocated to roots from mature source leaves (about $60 \%$ ) was significantly greater than that allocated to roots from recently mature source leaves (15 to $35 \%$ ) throughout the season (Table 2, Figure 3).

Ozone treatment effects on allocation of ${ }^{14} \mathrm{C}$ were most evident late in the season. The percent ${ }^{14} \mathrm{C}$ allocated from recently mature source leaves to roots was greater in $\mathrm{O}_{3}$-treated plants than in CF-treated plants from late July through midAugust (Figure 3 ). The increased ${ }^{14} \mathrm{C}$ allocation from recently mature source leaves to roots of $\mathrm{O}_{3}$-treated plants was at the expense of ${ }^{14} \mathrm{C}$ allocated to aboveground plant tissues (Figure 3 ). In contrast, the proportion of ${ }^{14} \mathrm{C}$ allocated from mature source leaves to roots was significantly less in $\mathrm{O}_{3}$-treated plants than in CF-treated plants in mid-August (Figure 3). Coincident with a decreased allocation to roots from mature leaves there was an increased allocation to the lower shoot. The shift in allocation from mature source leaves from roots to lower shoot began earlier and to a much greater extent in Clone 271 than in the other clones. The significant interaction between $\mathrm{O}_{3}$ and leaf position demonstrates the contrasting treatment effects of the two leaf positions on carbon allocation (Table 2).

\section{Carbon partitioning}

Partitioning of ${ }^{14} \mathrm{C}$ in source leaves Carbon partitioning in source leaves was affected in complex ways by $\mathrm{O}_{3}$ treatment, clone and leaf position (Table 3, Figure 4). The effect of $\mathrm{O}_{3}$ on percent ${ }^{14} \mathrm{C}$ varied among the chemical fractions. More ${ }^{14} \mathrm{C}$ was incorporated into the total sugar, lipids + pigments and organic acid fractions (Figure 4), whereas less ${ }^{14} \mathrm{C}$ was incorporated into the starch and protein fractions in $\mathrm{O}_{3}$-treated plants than in CF-treated plants. Clonal effects were evident for the total sugar and residue fractions (Table 3 , Figure 4 ). In recently mature leaves, Clone 271 had significantly less ${ }^{14} \mathrm{C}$ in the total sugar fraction than the other clones, whereas both Clones 259 and 271 had more ${ }^{14} \mathrm{C}$ in the residue than Clone 216. Partitioning of ${ }^{14} \mathrm{C}$ varied by leaf position; recently mature source leaves had less ${ }^{14} \mathrm{C}$ in the total sugar fraction, but more ${ }^{14} \mathrm{C}$ in the starch (CF plants), residue (Clones 259 and 271) and lipids + pigments fractions (both $\mathrm{CF}$ and $\mathrm{O}_{3}$ plants) than mature source leaves (Figure 4). There were also significant $\mathrm{O}_{3} \times$ clone interactions for ${ }^{14} \mathrm{C}$ incorporation into protein and organic acids, and significant $\mathrm{O}_{3} \times$ leaf position and clone $\times$ leaf position interactions on ${ }^{14} \mathrm{C}$ incorporation into the starch and organic acid fractions (Table 3 ).

Partitioning of ${ }^{14} \mathrm{C}$ in sink tissue Partitioning patterns were less evident in lower stem and coarse root sink tissues than in source leaves (Figures 5 and 6). Incorporation of ${ }^{14} \mathrm{C}$ into several chemical fractions was not affected by $\mathrm{O}_{3}$ or clone (Table 3). Percent ${ }^{14} \mathrm{C}$ (mean \pm standard deviation) of fractions showing no effects for the lower stem were: starch, $7.8 \pm 3.6 \%$ 
Table 3. Probability values for the percentage of ${ }^{14} \mathrm{C}$ found in chemical fractions of source leaves and in sink tissues of lower stem and coarse roots Source leaf analysis of variance was a three-way factorial design with $\mathrm{O}_{3}$ treatment, clone and leaf position as treatment factors. Lower stem and coarse root analysis of variance was a two-way factorial design with $\mathrm{O}_{3}$ treatment and clone as treatment factors.

\begin{tabular}{lcccccrr}
\hline $\begin{array}{l}\text { Source of } \\
\text { variation }\end{array}$ & $\begin{array}{l}\text { Total } \\
\text { sugar }\end{array}$ & Starch & Protein & $\begin{array}{l}\text { Amino } \\
\text { acids }\end{array}$ & $\begin{array}{l}\text { Organic } \\
\text { acids }\end{array}$ & $\begin{array}{l}\text { Lipids + } \\
\text { pigments }\end{array}$ & Residue \\
\hline $\begin{array}{l}\text { Source leaves } \\
\text { Ozone (O) }\end{array}$ & $0.049^{1}$ & 0.220 & 0.124 & 0.627 & 0.200 & 0.203 & 0.567 \\
Clone (C) & 0.032 & 0.467 & 0.849 & 0.214 & 0.296 & 0.719 & 0.002 \\
Position (P) & $<0.001$ & 0.007 & 0.293 & 0.818 & 0.022 & $<0.001$ & $<0.001$ \\
O $\times$ C & 0.380 & 0.303 & 0.052 & 0.764 & 0.022 & 0.468 & 0.511 \\
O $\times$ P & 0.289 & 0.004 & 0.123 & 0.447 & 0.069 & 0.018 & 0.988 \\
C $\times$ P & 0.446 & 0.028 & 0.140 & 0.157 & 0.010 & 0.801 & 0.003 \\
O $\times$ C P & 0.493 & 0.054 & 0.195 & 0.616 & 0.082 & 0.207 & 0.762 \\
Lower stem & & & & & & & \\
Ozone (O) & 0.085 & 0.877 & 0.064 & 0.057 & 0.741 & 0.598 & 0.221 \\
Clone (C) & 0.001 & 0.151 & 0.015 & 0.086 & 0.975 & 0.056 & 0.006 \\
O $\times$ C & 0.028 & 0.230 & 0.914 & 0.220 & 0.179 & 0.268 & 0.982 \\
Coarse roots & & & & & & & \\
Ozone (O) & 0.114 & 0.888 & 0.947 & 0.800 & 0.241 & 0.733 & 0.212 \\
Clone (C) & 0.014 & 0.971 & 0.514 & 0.019 & 0.051 & 0.570 & 0.043 \\
O $\times$ C & 0.009 & 0.464 & 0.315 & 0.617 & 0.248 & 0.391 & 0.063 \\
\hline
\end{tabular}

1 Probability values less than 0.10 are considered significant.

and organic acids, $4.2 \pm 1.2 \%$; and for the coarse roots were: starch, $9.0 \pm 3.7 \%$; protein, $5.0 \pm 1.7 \%$; and lipids + pigments, $5.6 \pm 0.8 \%$.

Few consistent responses in carbon partitioning related to either $\mathrm{O}_{3}$ treatment or clone were found among the chemical fractions in the lower stem and coarse roots. For example, incorporation of ${ }^{14} \mathrm{C}$ into both residue and protein fractions decreased with $\mathrm{O}_{3}$ treatment in the lower stem (Figure 5), but not in coarse roots (Table 2, Figure 6). The most interesting aspect of carbon partitioning in sink tissue was the variable clonal responses to $\mathrm{O}_{3}$. In the lower stem, incorporation of ${ }^{14} \mathrm{C}$ into total sugars increased with $\mathrm{O}_{3}$ treatment in Clones 216 and 271 , but not in Clone 259 , whereas ${ }^{14} \mathrm{C}$ incorporation into amino acids was greater for Clones 216 and 259, but not for Clone 271 (Figure 5). This response is shown as a significant $\mathrm{O}_{3} \times$ clone interaction for the sugar fraction (Table 3 ). In coarse roots of Clone $259, \mathrm{O}_{3}$ decreased ${ }^{14} \mathrm{C}$ in total sugars, but increased ${ }^{14} \mathrm{C}$ in the residue, organic acid and amino acid fractions (Figure 6). Ozone treatment had no effect on ${ }^{14} \mathrm{C}$ incorporation into coarse root chemical fractions of either Clone 216 or 271. This differential clonal response to $\mathrm{O}_{3}$ treatment resulted in a significant treatment $\times$ clone interaction for both the sugar and residue fractions (Table 3).

Chemical composition of source leaves The chemical composition of source leaves sampled in mid-August was affected by $\mathrm{O}_{3}$, clone and leaf position. In the $\mathrm{O}_{3}$-treated plants, concentrations of reducing sugars in recently mature source leaves were significantly lower, whereas concentrations of nonreducing sugars tended to be higher than in leaves of CF-treated plants; as a result, there was no significant treatment effect on the concentration of total sugars (Table 4, Figure 7). In contrast to recently mature leaves, mature source leaves from $\mathrm{O}_{3}$-treated plants had higher concentrations of reducing sugars but similar concentrations of nonreducing sugars compared with CFtreated plants. As a result, concentrations of total sugars were slightly greater in mature leaves of $\mathrm{O}_{3}$-treated plants than in mature leaves of CF-treated plants.

Starch concentrations were lower in recently mature leaves of $\mathrm{O}_{3}$-treated plants than in recently mature leaves of $\mathrm{CF}$ treated plants, but this effect was less pronounced in mature leaves (Table 4, Figure 7). Mature leaves of $\mathrm{O}_{3}$-treated plants had significantly lower concentrations of the lipids + pigments fraction and the water-methanol soluble fraction (mainly tannins and phenolics), and a significantly greater amount of residue compared to $\mathrm{CF}$-treated plants.

Chemical composition of sink tissue The concentrations of the chemical fractions of the lower stem differed little in response to treatment. Concentrations $\left(\mathrm{mg} \mathrm{g}^{-1}\right.$, mean \pm standard deviation) for each fraction were: residue, $788 \pm 26$; reducing sugars, $40 \pm 10$; nonreducing sugars, $23 \pm 10$; total sugars, $63 \pm 13$; water-methanol solubles, $50 \pm 10$; lipids + pigments, $44 \pm 7$; starch, $32 \pm 9$; and amino acids, $1.1 \pm 0.2$. Significant differences in the lower stem were associated with clones and $\mathrm{O}_{3} \times$ clonal interactions (Table 4). Ozone-treated plants of Clone 259 had greater concentrations of water-methanol solubles in stems than CF-treated plants (44.7 and $38.9 \mathrm{mg} \mathrm{g}^{-1}$, respectively). Of the three clones, Clone 259 had the lowest concentration of starch in lower stem tissue $\left(24.5 \mathrm{mg} \mathrm{g}^{-1}\right.$ versus 36.5 and $34.7 \mathrm{mg} \mathrm{g}^{-1}$ for Clones 216 and 271, respectively), and Clone 271 had the lowest concentration of amino acids $\left(0.98 \mathrm{mg} \mathrm{g}^{-1}\right.$ versus 1.14 and $1.17 \mathrm{mg} \mathrm{g}^{-1}$ for Clones 216 and 259 , respectively).

Chemical composition of coarse roots sampled in mid-August varied with $\mathrm{O}_{3}$ treatment and clone. With $\mathrm{O}_{3}$ treatment, 


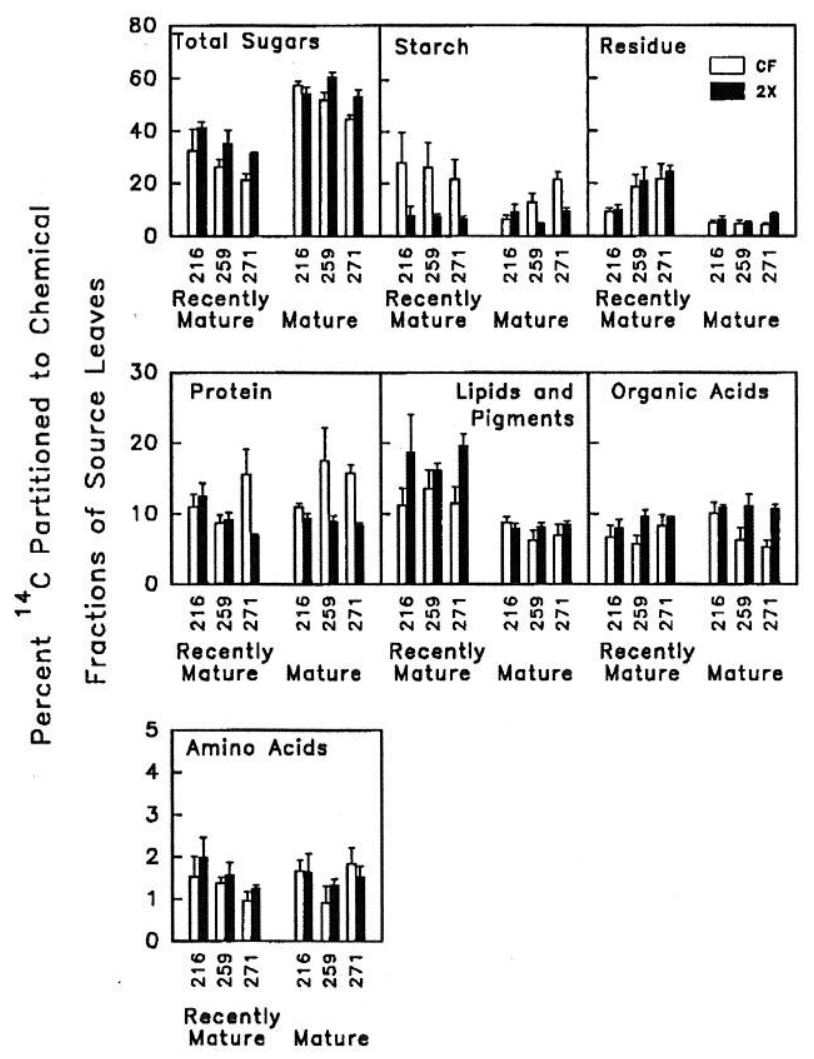

Figure 4. Effects of $\mathrm{O}_{3}$ exposure on ${ }^{14} \mathrm{C}$ partitioning among chemical fractions in source leaves. Labeled $\mathrm{CO}_{2}$ was applied to recently mature and mature leaves, and the plants were harvested after a 48 -h chase period. Three aspen clones $(216,259$ and 271$)$ were treated three times during the season. Ozone treatments were charcoal-filtered air (CF) and twice ambient $\mathrm{O}_{3}(2 \times)$. Chemical analyses to determine ${ }^{14} \mathrm{C}$ partitioning are from the mid-August samples only. The two leaf positions were considered separately because of significant positional effects in the statistical analysis. Each error bar represents the standard error of three replicate samples.

amino acids, water-methanol soluble and residue content increased in roots of $\mathrm{O}_{3}$-treated plants compared to roots of CF-treated plants, whereas sugar, starch and lipids + pigments concentrations decreased (Table 4, Figure 8). The response of Clone 259 to $\mathrm{O}_{3}$ was much greater than that of the other clones, especially for sugars, amino acids and residue components (Figure 8). In both the $\mathrm{CF}$ and $\mathrm{O}_{3}$ treatments, coarse roots of Clone 271 had significantly greater lipids + pigments and water-methanol concentrations, and less starch than the other clones.

Total carbon allocation to sink tissue The amount of carbon fixed and then allocated to sink tissue was much greater for recently mature leaves than for mature leaves (Figure 9, positional effect in Table 5). In mid-August, most of the carbon fixed in recently mature leaves was allocated to the lower shoot, whereas most carbon fixed by mature source leaves was allocated to roots. Significant carbon allocation to the shoot above recently mature leaves was found only in CF-treated plants of Clones 259 and 271. Carbon allocation to the lower shoot and roots decreased with $\mathrm{O}_{3}$ exposure in Clone 259. In contrast,

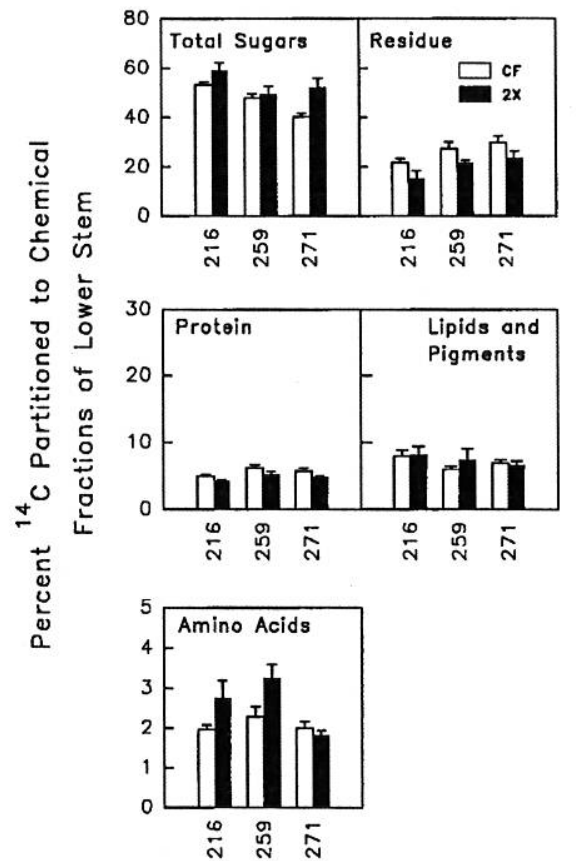

Figure 5. Effects of $\mathrm{O}_{3}$ exposure on ${ }^{14} \mathrm{C}$ partitioning among chemical fractions in lower stems. Labeled $\mathrm{CO}_{2}$ was applied to recently mature and mature leaves, and the plants were harvested after a 48 -h chase period. Three aspen clones $(216,259$ and 271$)$ were treated three times during the season. Ozone treatments were charcoal-filtered air (CF) and twice ambient $\mathrm{O}_{3}(2 \times)$. Chemical analyses to determine ${ }^{14} \mathrm{C}$ partitioning are from the mid-August samples only. The percentage of ${ }^{14} \mathrm{C}$ found in the different chemical fractions after labeling leaves from either of the two source leaf positions did not differ in the lower stems of plants; therefore, lower stem data from the two source leaf positions were combined in the statistical analysis. Each error bar represents the standard error of six replicate samples.

recently mature leaves of Clones 216 and 271 exposed to $\mathrm{O}_{3}$ were able to maintain carbon allocation equal to or greater than leaves of CF-treated plants. In Clone 271, this basipetal shift in carbon allocation in response to $\mathrm{O}_{3}$ decreased acropetal allocation. Total carbon allocation from mature source leaves to lower shoots and roots was always less in $\mathrm{O}_{3}$-treated plants than in CF-treated plants (Figure 9).

\section{Discussion}

Seasonal carbon allocation patterns in aspen were typical of indeterminately growing plants (Figure 3 ). Carbon supplied to the actively growing shoot tip and leaves came predominantly from the recently mature leaves directly below the developing leaf zone. As the season progressed, the percentage of carbon allocated acropetally from recently mature leaves decreased, whereas that allocated basipetally to the lower stem and roots increased. The lower leaves on the stem translocated virtually all carbon to lower stem and roots throughout the season. When the late season increase in carbon allocation from recently mature leaves was added to that supplied by mature source leaves, carbon allocation to roots increased dramatically. The seasonal response of aspen in this study (Figure 3) 


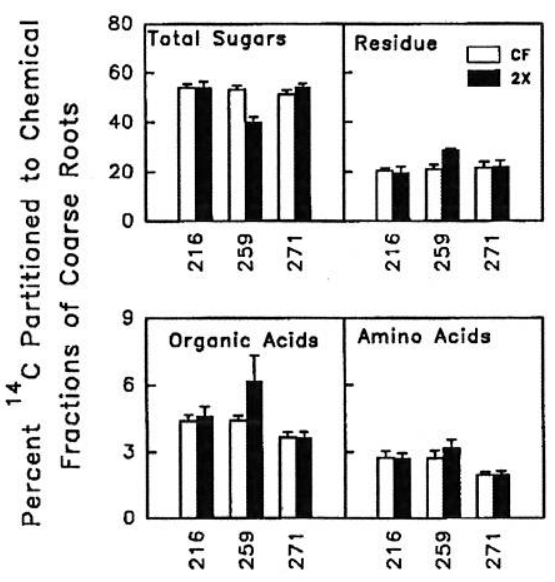

Figure 6. Effects of $\mathrm{O}_{3}$ exposure on ${ }^{14} \mathrm{C}$ partitioning among chemical fractions in coarse roots. Labeled $\mathrm{CO}_{2}$ was applied to recently mature and mature leaves, and the plants were harvested after a 48 -h chase period. Three aspen clones $(216,259$ and 271) were treated three times during the season. Ozone treatments were charcoal-filtered air (CF) and twice ambient $\mathrm{O}_{3}(2 x)$. Chemical analyses to determine ${ }^{14} \mathrm{C}$ partitioning are from the mid-August samples only. The percentage of ${ }^{14} \mathrm{C}$ found in the different chemical fractions after labeling leaves from either of the two source leaf positions did not differ in coarse roots of plants; therefore, root data from the two source leaf positions were combined in the statistical analysis. Each error bar represents the standard error of six replicate samples.

was the same as that found in other Populus species (Nelson and Dickson 1981, Dickson and Nelson 1982, Dickson 1986, 1991). These typical carbon allocation patterns of different leaf age classes were largely unchanged by $\mathrm{O}_{3}$ exposure. However, some shifts in carbon allocation patterns to compensate for $\mathrm{O}_{3}$ damage did occur, particularly in the $\mathrm{O}_{3}$-tolerant Clone 271 .

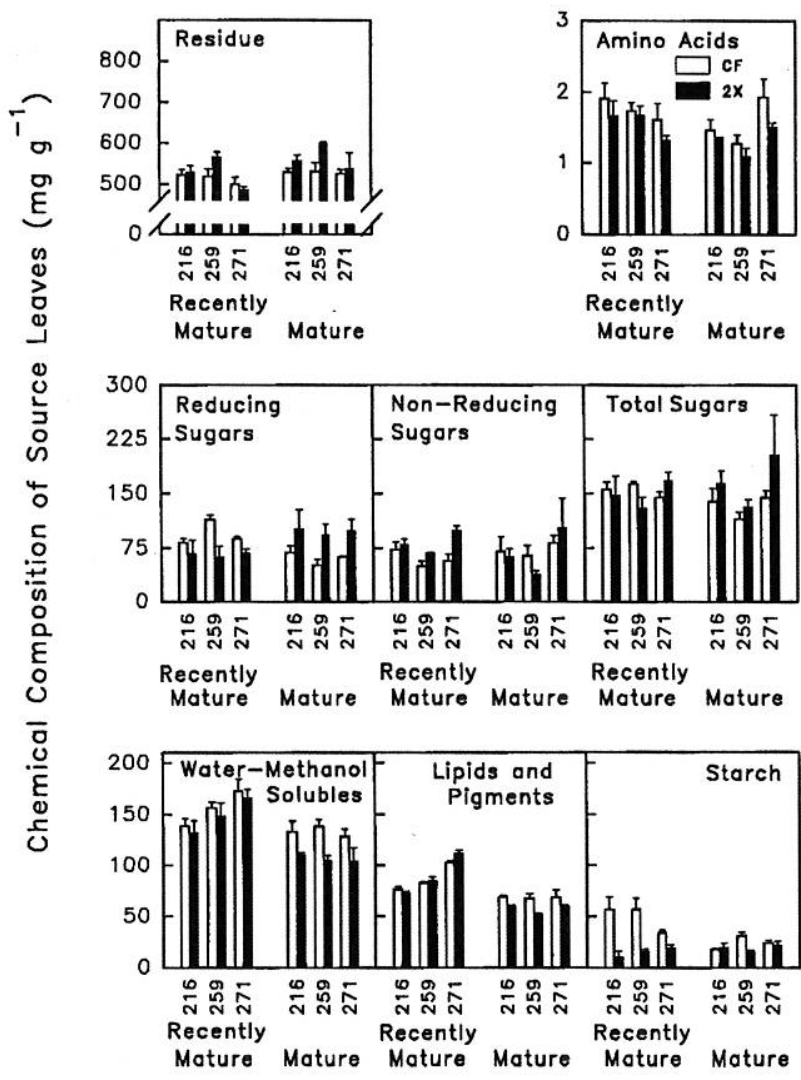

Figure 7. Effects of $\mathrm{O}_{3}$ exposure on chemical composition of source leaves. Ozone treatments were charcoal-filtered air $(\mathrm{CF})$ and twice ambient $\mathrm{O}_{3}(2 \times)$. Chemical analyses of leaves from the three aspen clones $(216,259$, and 271) are from the mid-August samples only. The two leaf positions were considered separately due to significant posi tional effects in the statistical analysis. Each error bar represents the standard error of three replicate samples.

Table 4. Probability values for the chemical composition of source leaves and sink tissues of lower stem and coarse roots from plants sampled in mid-August. Source leaf analysis of variance was a three-way factorial design with $\mathrm{O}_{3}$ treatment, clone and leaf position as treatment factors. Lower stem and coarse root analysis of variance was a two-way factorial design with $\mathrm{O}_{3}$ treatment and clone as treatment factors.

\begin{tabular}{|c|c|c|c|c|c|c|c|c|}
\hline $\begin{array}{l}\text { Source of } \\
\text { variation }\end{array}$ & $\begin{array}{l}\text { Reducing } \\
\text { sugars }\end{array}$ & $\begin{array}{l}\text { Nonreducing } \\
\text { sugars }\end{array}$ & $\begin{array}{l}\text { Total } \\
\text { sugars }\end{array}$ & Starch & $\begin{array}{l}\text { Amino } \\
\text { acids }\end{array}$ & $\begin{array}{l}\text { Water-methanol } \\
\text { solubles }\end{array}$ & $\begin{array}{l}\text { Lipids + } \\
\text { pigments }\end{array}$ & Residue \\
\hline \multicolumn{9}{|l|}{ Source leaves } \\
\hline Ozone (O) & 0.467 & 0.288 & 0.174 & $0.000^{1}$ & 0.054 & 0.005 & 0.069 & 0.017 \\
\hline Clone (C) & 0.992 & 0.030 & 0.072 & 0.531 & 0.410 & 0.115 & $<0.001$ & 0.009 \\
\hline Position (P) & 0.888 & 0.885 & 0.831 & 0.013 & 0.056 & $<0.001$ & $<0.001$ & 0.016 \\
\hline $\mathrm{O} \times \mathrm{C}$ & 0.633 & 0.193 & 0.152 & 0.138 & 0.646 & 0.881 & 0.322 & 0.068 \\
\hline $\mathrm{O} \times \mathrm{P}$ & 0.000 & 0.135 & 0.059 & 0.001 & 0.874 & 0.079 & 0.004 & 0.235 \\
\hline $\mathrm{C} \times \mathrm{P}$ & 0.219 & 0.458 & 0.255 & 0.414 & 0.017 & 0.022 & $<0.001$ & 0.663 \\
\hline $\mathrm{O} \times \mathrm{C} \times \mathrm{P}$ & 0.297 & 0.750 & 0.944 & 0.182 & 0.850 & 0.915 & 0.421 & 0.992 \\
\hline \multicolumn{9}{|l|}{ Lower stem } \\
\hline Ozone $(\mathrm{O})$ & 0.750 & 0.235 & 0.494 & 0.249 & 0.177 & 0.011 & 0.206 & 0.451 \\
\hline Clone (C) & 0.265 & 0.349 & 0.313 & 0.005 & 0.006 & 0.816 & 0.420 & 0.544 \\
\hline $\mathrm{O} \times \mathrm{C}$ & 0.547 & 0.970 & 0.666 & 0.616 & 0.215 & 0.072 & 0.648 & 0.914 \\
\hline \multicolumn{9}{|l|}{ Coarse roots } \\
\hline Ozone $(\mathrm{O})$ & 0.046 & 0.128 & 0.009 & 0.060 & 0.034 & 0.001 & 0.099 & 0.018 \\
\hline Clone (C) & 0.204 & 0.000 & $<0.001$ & 0.025 & 0.093 & $<0.001$ & $<0.001$ & 0.008 \\
\hline $\mathrm{O} \times \mathrm{C}$ & 0.013 & 0.725 & 0.044 & 0.732 & 0.109 & 0.459 & 0.753 & 0.176 \\
\hline
\end{tabular}

\footnotetext{
${ }^{1}$ Probability values less than 0.10 are considered significant.
} 

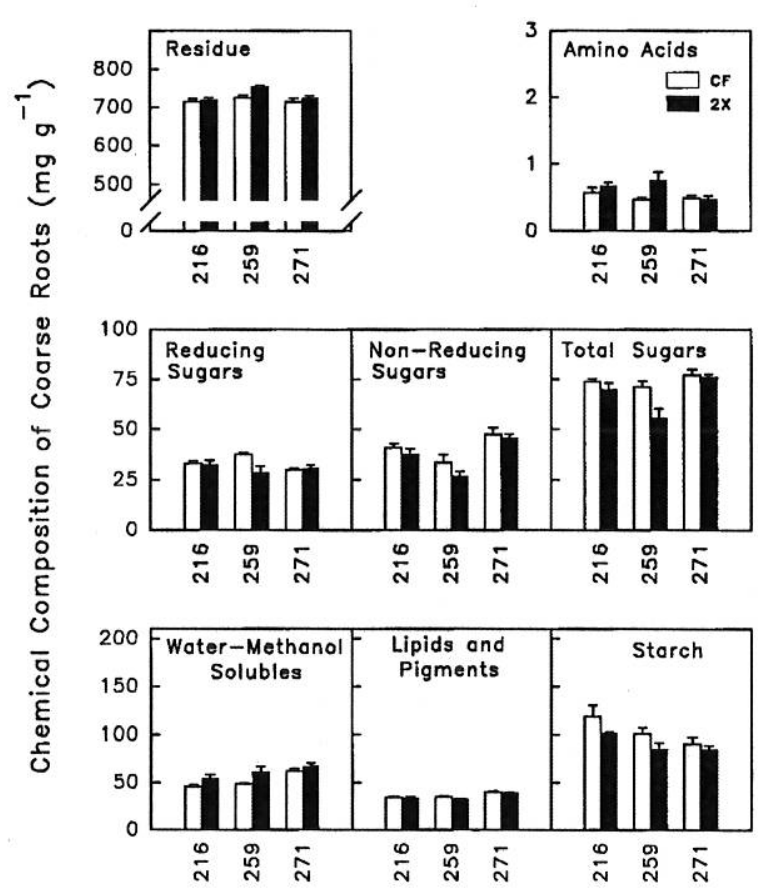

Figure 8. Effects of $\mathrm{O}_{3}$ exposure on chemical composition of coarse roots. Ozone treatments were charcoal-filtered air (CF) and twice ambient $\mathrm{O}_{3}(2 \times)$. Chemical analyses of roots from the three aspen clones $(216,259$ and 271) are from the mid-August samples only. Each error bar represents the standard error of six replicate samples.

Table 5. Probability values for the amount of carbon allocated to sink tissues of upper shoot, lower shoot and roots from plants sampled in mid-August. Each analysis of variance was a three-way factorial design with $\mathrm{O}_{3}$ treatment, clone and leaf position as treatment factors.

\begin{tabular}{llcr}
\hline Variation & \multicolumn{4}{l}{ Amount of carbon allocated to } \\
\cline { 2 - 4 } & Upper shoot & Lower shoot & Roots \\
\hline Ozone (O) & $0.072^{1}$ & 0.345 & 0.308 \\
Clone (C) & 0.166 & 0.117 & 0.002 \\
Position (P) & 0.047 & $<0.001$ & $<0.001$ \\
O $\times$ C & 0.279 & 0.102 & 0.031 \\
O $\times$ P & 0.124 & 0.159 & 0.534 \\
$\mathrm{C} \times \mathrm{P}$ & 0.210 & 0.219 & 0.001 \\
O $\times \mathrm{C} \times \mathrm{P}$ & 0.346 & 0.082 & 0.005 \\
\hline
\end{tabular}

${ }^{1}$ Probability values less than 0.10 are considered significant.

In many species, $\mathrm{O}_{3}$ decreases root biomass accumulation more than shoot biomass accumulation (Cooley and Manning 1987). Shoots may receive a greater proportion of the limited assimilates as a result of decreased phloem loading (McLaughlin and McConathy 1983), decreased phloem transport (Spence et al. 1990), or greater carbon demands for repair of $\mathrm{O}_{3}$-damaged foliage (McLaughlin and McConathy 1983). Additionally, photosynthetic carbon fixation rates of mature leaves exposed to $\mathrm{O}_{3}$ stress are severely inhibited (Reich 1983, Coleman et al. 1995). Because lower leaves have a major role in supplying roots with carbon, $\mathrm{O}_{3}$ stress should inhibit root growth to a greater extent than shoot growth. However, in some

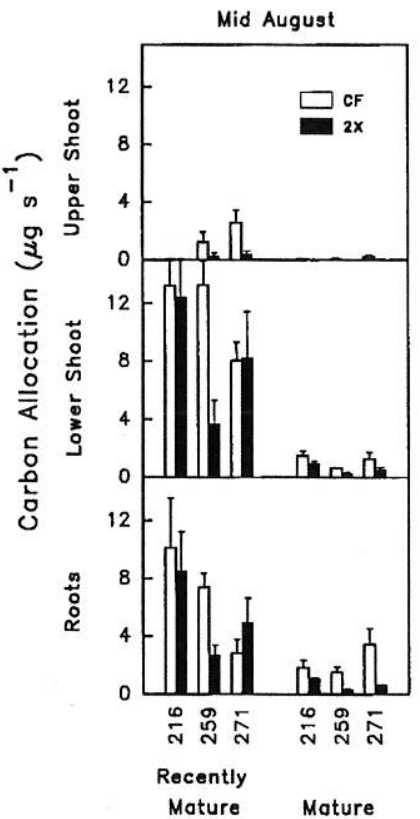

Figure 9. Effects of $\mathrm{O}_{3}$ exposure on total carbon allocated within the plant. Sink tissue types (upper shoot, lower shoot and root) are dia grammed in Figure 1. Carbon allocation within the three aspen clones $\left(216,259\right.$ and 271) was calculated from the percentage of ${ }^{14} \mathrm{C}$ allocated to each sink and the photosynthetic productivity of the recently mature and mature leaf age classes in mid-August. Ozone treatments were charcoal-filtered air $(\mathrm{CF})$ and twice ambient $\mathrm{O}_{3}(2 \times)$. Each error bar represents the standard error of three replicate samples.

species allocation of carbon to biomass of both aboveground and belowground plant parts declines equally with $\mathrm{O}_{3}$ treatment, and shoot/root ratios remain constant (Cooley and Manning 1987). Aspen appears to fit this pattern of response because shoot/root ratios were unaffected by $\mathrm{O}_{3}$ treatment $(P=$ 0.485; Karnosky, unpublished data). Although the amount of carbon allocated from mature leaves to roots was severely inhibited by $\mathrm{O}_{3}$ treatment in aspen, recently mature leaf carbon allocation shifted to favor roots at the expense of the shoot, thus compensating for decreased carbon allocation from mature leaves to roots (Figures 3 and 9).

Carbon partitioning patterns in leaves can vary diurnally in response to accumulation and translocation of assimilates (Huber 1983, Dickson 1987, 1991). Additionally, other plant and environmental factors can have a large influence on leaf carbon metabolism (Geiger 1979, Stitt 1987, Rufty et al. 1988). Carbon partitioning in aspen source leaf tissue responded to $\mathrm{O}_{3}$ stress to a much greater extent than that in sink tissues (Tables 3 and 4). The most significant response to $\mathrm{O}_{3}$ stress in aspen was found in leaf tissues where ${ }^{14} \mathrm{C}$ incorporation into starch was less than half that of the CF-treated plants (Figure 4), resulting in substantial decreases in the total starch concentration, especially in recently mature leaves (Figure 7). Coarse root starch concentrations also decreased with $\mathrm{O}_{3}$ treatment (Figure 8). Similar declines in starch concentrations in response to $\mathrm{O}_{3}$ have been found for Pinus taeda L. (Meier et al. 1990, Friend et al. 1992), Pinus ponderosa Laws. (Miller et 
al. 1969), Pinus echinata Mill. (Paynter et al. 1991), Gossypium hirsutum L. (Miller et al. 1989) and Trifolium repens $\mathrm{L}$. (Blum et al. 1982). There are, however, cases where $\mathrm{O}_{3}$ exposure increased starch concentrations in shoots (Tingey et al. 1976).

Incorporation of ${ }^{14} \mathrm{C}$ into sugar generally increased with $\mathrm{O}_{3}$ exposure in source leaf and lower stem tissue (Figures 4 and 5 ); however, total sugar concentrations were mostly unchanged because of differential incorporation into the different sugar fractions. For example, reducing sugar concentrations decreased in recently mature leaf tissue, whereas nonreducing sugar concentrations increased. At the same time, both sugar fractions and total sugars tended to increase in mature leaves. Similar complex responses to $\mathrm{O}_{3}$ treatment have been found in Pinus species (Barnes 1972, Tingey et al. 1976, Paynter et al. 1991). Decreases in starch and increases in soluble sugars are a common response to $\mathrm{O}_{3}$ exposure (Friend et al. 1992).

To determine how shifts in carbon allocation patterns affected growth, we calculated the total amount of carbon translocated to sink tissue from photosynthetic data and the percent ${ }^{14} \mathrm{C}$ allocated to different tissues. Ozone significantly decreased mature leaf photosynthetic rate. This negative effect was similar in magnitude for all clones. In contrast, $\mathrm{O}_{3}$ effects on recently mature leaf photosynthetic rate differed among the clones: photosynthesis was unaffected in Clone 216, significantly decreased in Clone 259, and slightly increased in Clone 271. In addition to decreases in photosynthetic rate, abscission of mature leaves was observed to varying degrees in all clones, and $\mathrm{O}_{3}$ treatment significantly increased the loss of mature leaves. Clones 216 and 259 lost more leaf area than Clone 271 (Coleman et al. 1995). Because of decreases in photosynthetic rate and loss of leaves in the $\mathrm{O}_{3}$-treated clones, much less photosynthate was available for transport to sinks. For example, in Clone 259, when the rate of $7.4 \mu \mathrm{g} \mathrm{s}^{-1}$ of carbon allocated to roots from the recently mature leaves of CF plants is totaled for $8 \mathrm{~h}$ per day over 100 days, an accumulation of $21.3 \mathrm{~g}$ of carbon is predicted. This approach assumes that the midday photosynthetic rate holds for $8 \mathrm{~h}$ and represents the cumulative daily photosynthetic productivity, and that the amount retained after the 48 -h chase period represents dry matter accumulation. The corresponding values for $\mathrm{O}_{3}$-treated plants of Clone 259 were $2.7 \mu \mathrm{g}$ allocated $\mathrm{s}^{-1}$ and $7.7 \mathrm{~g}$ accumulated, respectively. Adding the contribution of mature leaves, the total accumulation was 25.6 and $8.6 \mathrm{~g}$ for CFtreated and $\mathrm{O}_{3}$-treated plants, respectively.

The differing clonal responses in carbon allocation to $\mathrm{O}_{3}$ treatment provide information about the mechanisms of variable sensitivities. All clones increased the percent of carbon allocated from recently mature leaves to lower stem and root tissue following terminal bud set, but Clone 271 appeared to make adjustments sooner and to a greater extent than the other clones. Clone 271 was exceptional in its ability to compensate for $\mathrm{O}_{3}$ stress. Not only were plants of this clone able to shift a greater proportion of carbon to sinks in the lower portion of the plant, but the recently mature leaves also compensated by increasing their photosynthetic rate. As a result, there was no apparent $\mathrm{O}_{3}$ effect on carbon allocation to sink tissue in this clone (Figure 9). Ozone has been shown to increase the photosynthetic rate of retained foliage in other tree species (Eamus et al. 1990), and this increase may result from increased sink demand of the diminishing leaf area. Photosynthetic rate of retained leaves is known to increase in Populus following artificial defoliation (Bassman and Dickmann 1982), and this photosynthetic adjustment was associated with shifts in carbon allocation (Bassman and Dickmann 1985). It is reasonable, therefore, to expect a similar response in $\mathrm{O}_{3}$-stressed aspen in which mature leaves senesce and abscise prematurely.

There was a negative effect of $\mathrm{O}_{3}$ on the total amount of carbon transported in the $\mathrm{O}_{3}$-sensitive Clone 259 (Figure 9, cf. Karnosky et al. 1992). Sensitivity of Clone 259 is related to decreases in photosynthetic rate and loss of lower leaves rather than to changes in carbon allocation. Carbon allocation from recently mature leaves did shift basipetally to compensate for loss of photosynthate from lower mature leaves. This shift in carbon allocation, however, could not compensate for overall loss of productivity resulting from $\mathrm{O}_{3}$ exposure of Clone 259 .

Ranking of these clones with respect to $\mathrm{O}_{3}$ sensitivity was originally based on relative decreases in biomass production and foliar injury in response to $\mathrm{O}_{3}$ exposure. Based on decreases in biomass with $\mathrm{O}_{3}$ exposure, in 1989 the clones were ranked $216>271>259$ (Karnosky et al. 1992). In 1990, biomass rankings were the same. In 1991, based on decreases in biomass, the clones ranked $271>216>259$ (Karnosky, unpublished data). Small changes in environmental or experimental parameters may change the relative biomass production of Clones 216 and 271, both of which are relatively tolerant to $\mathrm{O}_{3}$ exposure compared to Clone 259. Our data indicate that tolerance is determined largely by the photosynthetic response to $\mathrm{O}_{3}$ exposure, and that this response differs significantly among the three clones (Coleman et al. 1995).

In summary, seasonal patterns of carbon allocation found in this study were typical of indeterminately growing plants where carbon transported from recently mature leaves moves both acropetally and basipetally until terminal bud set. Following terminal bud set, all leaves on the plant transport carbon basipetally. Ozone effects on carbon allocation patterns were more apparent later in the season. Mature leaves translocated significantly less ${ }^{14} \mathrm{C}$ to the roots when exposed to $\mathrm{O}_{3}$. Recently mature leaves increased carbon allocation to roots with $\mathrm{O}_{3}$ exposure in an apparently compensatory response. This compensation by recently mature leaves resulted in $\mathrm{O}_{3}$ having negligible effects on the shoot/root ratio. Although the adjustments of carbon allocation from recently mature source leaves to different sinks distributed the impact of $\mathrm{O}_{3}$ more evenly throughout the plant, the greatest impact of $\mathrm{O}_{3}$ was on total carbon gain (cf. Coleman et al. 1995). Those clones that retained relatively greater leaf area and photosynthetic rate were most successful at maintaining productivity at rates similar to CF-treated plants.

\section{Acknowledgments}

We gratefully acknowledge the technical assistance given by Zophie Gagnon for plant culture and $\mathrm{O}_{3}$ treatments, Bill Vaughn for ${ }^{14} \mathrm{C}$ applications, and Gary Garton and Beth Hair for laboratory analysis. 
Funding was provided by USDA CSRS grant \#89-34171-4384, US EPA grant \#DW12934109-0, and by USDA Forest Service, Northern Stations Global Change Research Program. This paper was presented at an international workshop entitled "Ecophysiology and Genetics of Trees and Forests in a Changing Environment" in Viterbo, Italy, in May 1993.

\section{References}

Adams, M.B. and E.G. O'Neill. 1991. Effects of ozone and acidic deposition on carbon allocation and mycorrhizal colonization of Pinus taeda L. seedlings. For. Sci. 37:5-16.

Adams, M.B., N.T. Edwards, G.E. Taylor, Jr. and B.L. Skaggs. 1990. Whole-plant ${ }^{14} \mathrm{C}$-photosynthate allocation in Pinus taeda: seasonal patterns at ambient and elevated ozone levels. Can. J. For. Res. 20:152-158.

Anonymous. 1993. Northeastern area forest health report. USDA Forest Service, NE, Report No. NA-TP-03-93.

Barnes, R.L. 1972. Effects of chronic exposure to ozone on soluble sugar and ascorbic acid contents of pine seedlings. Can. J. Bot. 50:215-219.

Bassman, J.H. and D.I. Dickmann. 1982. Effects of defoliation in the developing leaf zone on young Populus $\times$ euramericana plants. I. Photosynthetic physiology, growth, and dry weight partitioning. For. Sci. 28:599-612.

Bassman, J.H. and D.I. Dickmann. 1985. Effects of defoliation in the developing leaf zone on young Populus $\times$ euramericana plants. II. Distribution of ${ }^{14} \mathrm{C}$-photosynthate after defoliation. For. Sci. 31:358-366.

Blum, U., G.R. Smith and R.C. Fites. 1982. Effects of multiple $\mathrm{O}_{3}$ exposures on carbohydrate and mineral contents of ladino clover. Environ. Exp. Bot. 22:143-154.

Brouwer, R. 1983. Functional equilibrium: sense or nonsense? Neth. J. Agric. Sci. 31:335-348.

Bücker, J. and H.J. Ballach. 1992. Alterations in carbohydrate levels in leaves of Populus due to ambient air pollution. Physiol. Plant. 86:512-517.

Butler, L.K. and T.W. Tibbitts. 1979. Stomatal mechanisms determining genetic resistance to ozone in Phaseolus vulgaris L. J. Am. Soc. Hortic. Sci. 104:213-216.

Coleman, M.D., R.E. Dickson, J.G. Isebrands and D.F. Karnosky. 1995. Photosynthetic productivity of aspen clones varying in sensitivity to tropospheric ozone. Tree Physiol. 15:585-592.

Cooley, D.R. and W.J. Manning. 1987. The impact of ozone on assimilate partitioning in plants: a review. Environ. Pollut. 47:95113.

Dickson, R.E. 1979. Analytical procedures for the sequential extraction of ${ }^{14} \mathrm{C}$-labeled constituents from leaves, bark and wood of cottonwood plants. Physiol. Plant. 45:480-488.

Dickson, R.E. 1986. Carbon fixation and distribution in young Populus trees. In Crown and Canopy Structure in Relation to Productivity. Eds. T. Fujimori and D. Whitehead. Forestry and Forest Products Research Institute, Ibaraki, Japan, pp 409-426.

Dickson, R.E. 1987. Diurnal changes in leaf chemical constituents and ${ }^{14} \mathrm{C}$ partitioning in cottonwood. Tree Physiol. 3:157-171.

Dickson, R.E. 1991. Assimilate distribution and storage. In Physiology of Trees. Ed. A.S. Raghavendra. John Wiley and Sons, New York, New York, pp 51-85.

Dickson, R.E. and J.G. Isebrands. 1991. Leaves as regulators of stress response. In Response of Plants to Multiple Stresses. Eds. H.A. Mooney, E.J. Pell and W.E. Winner. Academic Press, New York, New York, pp 3-34.
Dickson, R.E. and J.G. Isebrands. 1993. Carbon allocation terminol ogy: should it be more rational? Bull. Ecol. Soc. Am. 74:175-177.

Dickson, R.E. and E.A. Nelson. 1982. Fixation and distribution of ${ }^{14} \mathrm{C}$ in Populus deltoides during dormancy induction. Physiol. Plant. $54: 393-401$.

Eamus, D., J.D. Barnes, L. Mortensen, H. Ro-Poulsen and A.W. Davison. 1990. Persistent stimulation of $\mathrm{CO}_{2}$ assimilation and stomatal conductance by summer ozone fumigation in Norway spruce. Environ. Pollut. 63:365-379.

Friend, A.L., P.T. Tomlinson, R.E. Dickson, E.G. O'Neill, N.T. Edwards and G.E. Taylor, Jr. 1992. Biochemical composition of loblolly pine reflects pollutant exposure. Tree Physiol. 11:35-47.

Geiger, D.R. 1979. Control of partitioning and export of carbon in leaves of higher plants. Bot. Gaz. 140:241-248.

Gillespie, C.T. and W.E. Winner. 1989. Development of lines of radish differing in resistance to $\mathrm{O}_{3}$ and $\mathrm{SO}_{2}$. New Phytol. 112:353-361.

Gorissen, A. and J.A. van Veen. 1988. Temporary disturbance of translocation of assimilates in Douglas-fir caused by low levels of ozone and sulfur dioxide. Plant Physiol. 88:559-563.

Gorissen, A., N.N. Joosten and A.E. Jansen. 1991a. Effects of ozone and ammonium sulphate on carbon partitioning to mycorrhizal roots of juvenile Douglas-fir. New Phytol. 119:243-250.

Gorissen, A., G.C. Schelling and J.A.van Veen. 1991b. Concentrationdependent effects of ozone on translocation of assimilates in Douglas-fir. J. Environ. Qual. 20:169-173.

Heck, W.W., J.A. Dunning, R.A. Reinert, S.A. Prior, M. Rangappa and P.S. Benepal. 1988. Differential responses of four bean cultivars to chronic doses of ozone. J. Am. Soc. Hortic. Sci. 113:46-51.

Huber, S.C. 1983. Relation between photosynthetic starch formation and dry-weight partitioning between the shoot and root. Can. J. Bot. 61:2709-2716.

Isebrands, J.G. and R.E. Dickson. 1991. Measuring carbohydrate production and distribution: radiotracer techniques and applica tions. In Techniques and Approaches in Forest Tree Ecophysiology. Eds. J.P. Lassoie and T.M. Hinckley. CRC Press, Boca Raton, Florida, USA, pp 357-392.

Karnosky, D.F., Z.E. Gagnon, D.D. Reed and J.A. Witter. 1992. Growth and biomass allocation of symptomatic and asymptomatic Populus tremuloides clones in response to seasonal ozone exposures. Can. J. For. Res. 22:1785-1788.

Lefohn, A.S. and J.E. Pinkerton. 1988. High resolution characterization of ozone data for sites located in forested areas of the United States. J. Air Pollut. Control Assoc. 38:1504-1511.

McCool, P.M. and J.A. Menge. 1983. Influence of ozone on carbon partitioning in tomato: potential role of carbon flow in regulation of the mycorrhizal symbiosis under conditions of stress. New Phytol. 94:241-247.

McLaughlin, S.B. and R.K. McConathy. 1983. Effects of $\mathrm{SO}_{2}$ and $\mathrm{O}_{3}$ on allocation of ${ }^{14} \mathrm{C}$-labeled photosynthate in Phaseolus vulgaris. Plant Physiol. 73:630-635.

Meier, S., L.F. Grand, M.M. Schoeneberger, R.A. Reinert and R.I. Bruck. 1990. Growth, ectomycorrhizae and nonstructural carbohydrates of loblolly pine seedlings exposed to ozone and soil water deficit. Environ. Pollut. 64:11-27.

Miller, J.E., R.P. Patterson, W.A. Pursley, A.S. Heagle and W.W. Heck. 1989. Response of soluble sugars and starch in field-grown cotton to ozone, water stress, and their combination. Environ. Exp. Bot. 29:477-486.

Miller, P.R., J.R. Parmeter, Jr., B.H. Flick and C.W. Martinez. 1969. Ozone dosage response of ponderosa pine seedlings. J. Air Polllut. Control Assoc. 19:435-438. 
Nelson, E.A. and R.E. Dickson. 1981. Accumulation of food reserves in cottonwood stems during dormancy induction. Can. J. For. Res. 11:145-154.

Paynter, V.A., J.C. Reardon and V.B. Shelburne. 1991. Carbohydrate changes in shortleaf pine (Pinus echinata) needles exposed to acid rain and ozone. Can. J. For. Res. 21:666-671.

Reich, P.B. 1983. Effects of low concentrations of $\mathrm{O}_{3}$ on net photosynthesis, dark respiration, and chlorophyll contents in aging hybrid poplar leaves. Plant Physiol. 73:291-296.

Reich, P.B. 1987. Quantifying plant response to ozone: a unifying theory. Tree Physiol. 3:63-91.

Rufty, T.W., S.C. Huber and RJ. Volk. 1988. Alterations in leaf carbohydrate metabolism in response to nitrogen stress. Plant Physiol. 88:725-730.
Spence, R.D., E.J. Rykiel, Jr. and P.J.H. Sharpe. 1990. Ozone alters carbon allocation in loblolly pine: assessment with carbon-11 label ing. Environ. Pollut. 64:93-106.

Stitt, M. 1987. Fructose 2,6-bisphosphate and plant carbohydrate metabolism. Plant Physiol. 84:201-204.

Tingey, D.T. 1974. Ozone induced alterations in the metabolite pools and enzyme activities of plants. In Air Pollution Effects on Plant Growth. ACS Symposium, No. 3, American Chemical Society, pp 40-57.

Tingey, D.T., R.G. Wilhour and C. Standley. 1976. The effect of chronic ozone exposures on the metabolite content of ponderosa pine seedlings. For. Sci. 22:234-241.

Wilkinson, L. 1990. SYSTAT: The system for statistics. SYSTAT Inc., Evanston, Illinois, 724 p. 